\title{
Spatial and temporal patterns of Populus tremuloides regeneration in small forest openings in northern Ontario
}

\author{
by Arthur Groot ${ }^{1}$, Rongzhou Man² and Jim Wood ${ }^{3}$
}

\begin{abstract}
The density, height and diameter of trembling aspen sucker regeneration was assessed over a 10-year period in openings created by harvesting in a 40-year-old, 19-m-tall aspen stand in northeastern Ontario. The 5 types of opening comprised: circular openings of 9-m- and 18-m-diameter, 150 -m-long east-west strips of 9-m and 18-m width, and a 1.5 ha (100 m $\times 150 \mathrm{~m}$ ) clearcut. Density of aspen regeneration was significantly affected by opening type, location relative to the opening, time since harvest, and by all interactions of these factors. Aspen densities within the circular openings declined to low levels by year 10, despite considerable initial recruitment. Trembling aspen height and diameter were significantly influenced by opening type, location relative to the opening, time since harvest, and by opening $\times$ time and location $\times$ time interactions. Trembling aspen heights in the circular openings were substantially less than in the clearcut and strip openings by year 10. The results support the traditional view that aspen is best managed under the clearcut silvicultural system, and that trembling aspen regeneration following forest harvesting can be reduced by controlling the extent or intensity of overstory removal. Finally, the results suggest that disturbances that create gaps greater than 1 tree height in width in aspen or mixedwood forests may allow gap dynamics to function.
\end{abstract}

Key words: trembling aspen, silviculture, boreal mixedwoods, regeneration, forest openings

\section{RÉSUMÉ}

La densité, la hauteur et le diamètre de la régénération de tremble issue de drageons ont été mesurées au cours d'une période de dix ans dans les ouvertures créées par la récolte d'un peuplement de tremble de 40 ans et de $19 \mathrm{~m}$ de hauteur dans le nord-est de l'Ontario. Les cinq types d'ouvertures retrouvées sur le site comprenaient des ouvertures circulaires de $9 \mathrm{~m}$ et de $18 \mathrm{~m}$ de diamètre, des bandes de $150 \mathrm{~m}$ de long orientées dest en ouest de $9 \mathrm{~m}$ et de $18 \mathrm{~m}$ de largeur et une coupe à blanc de 1,5 ha $(100 \times 150 \mathrm{~m})$. La densité de la régénération de tremble était significativement dépendante du type douverture, de la localisation relative de louverture, du temps écoulé depuis la récolte et par l'interaction de ces facteurs. La densité de tremble dans les ouvertures circulaires a diminué année après année, malgré le nombre important de recrues initialement. La hauteur et le diamètre ont été significativement dépendants du type douverture, de la localisation relative de louverture, du temps écoulé depuis la récolte et par l'interaction entre l'ouverture et le temps écoulé ainsi quentre la localisation et le temps écoulé. La hauteur des trembles dans les ouvertures circulaires était substantiellement moindres que dans les ouvertures par coupe et par bande 10 ans après la récolte. Les résultats appuient lopinion traditionnelle que le tremble est mieux aménagé au moyen d'un régime sylvicole de coupe à blanc et que la régénération de tremble à la suite d'une récolte de bois peut être réduite par le contrôle de l'étendue ou de lintensité de la coupe du couvert dominant. Finalement les résultats laissent entendre que les perturbations qui créent des ouvertures plus importantes en largeur que la hauteur d'un arbre dans les tremblaies ou dans les peuplements mélangés pourraient introduire des ratés dans la dynamique naturelle de ces peuplements.

Mots clés : peuplier faux-tremble, sylviculture, peuplements mélangés nordiques, régénération, ouvertures des peuplements

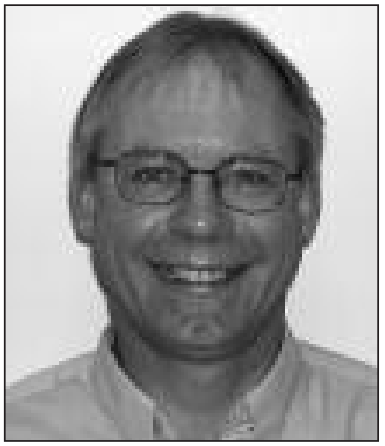

Arthur Groot

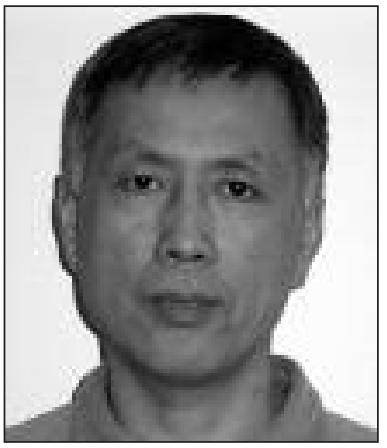

Rongzhou Man

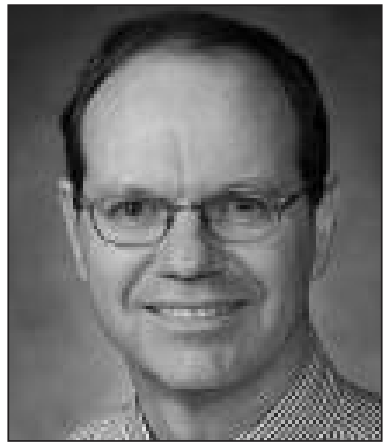

$\operatorname{Jim}$ Wood

\footnotetext{
${ }^{1}$ Natural Resources Canada, Canadian Wood Fibre Centre, 1219 Queen St. E., Sault Ste. Marie, Ontario P6A 2E5. Corresponding author. E-mail: agroot@nrcan.gc.ca.

${ }^{2}$ Ontario Ministry of Natural Resources, Ontario Forest Research Institute, 1235 Queen St. E., Sault Ste. Marie, Ontario P6A 2 E5.

${ }^{3}$ Natural Resources Canada, Pacific Forestry Centre, 506 West Burnside Road, Victoria, British Columbia V8Z 1 M5.
} 


\section{Introduction}

Trembling aspen (Populus tremuloides Michx.) is a shadeintolerant tree species that is widely distributed throughout the boreal forest of North America. Aspen is well-adapted to regenerate after intense disturbances-caused by agents such as fire, wind, insect attack and forest harvesting-that result in complete or near complete mortality of the overstory. In these circumstances, aspen regenerates profusely by root suckering in response to increased soil temperature and the changed balance of hormonal growth regulators caused by overstory stem mortality (Frey et al. 2003). Less frequently, dense aspen regeneration establishes from seed following intense disturbance (Doucet 1989, Quinn and Wu 2001). Aspen suckers and seedlings grow rapidly in the full-light environment created by mortality or removal of the overstory. Even-aged stands of aspen are widespread as a result of the vigorous regeneration that follows intense disturbances. Correspondingly, the clearcut silvicultural system is considered well-suited to aspen management (Doucet 1989).

Although trembling aspen response to extensive and complete mortality or removal of the overstory is well-understood, several uncertainties in aspen silviculture and ecology require greater understanding of aspen response to partial or local overstory removal.

The first uncertainty relates to the need to reduce the density and growth of aspen regeneration following forest harvesting in order to enhance establishment and growth of planted or natural conifers and therefore create mixedwood stands of desired composition and structure (MacDonald and Thompson 2003, MacDonald et al. 2004). It is generally evident that the density and development of aspen regeneration can be reduced by restricting the extent or intensity of canopy removal in forest harvests (Doucet 1989), but the specifics of this effect are not clear. Ohmann et al. (1978) suggested that the growth of regenerated aspen is strongly retarded in clearcuts less than 0.81 ha in area, but recent research indicates that the limiting area is considerably less (Groot et al. 1997, Kabzems 2001).

A second, complementary uncertainty is whether silvicultural systems alternative to extensive clearcutting can be used when aspen production is the management objective. Ruark (1990) speculated, for example, that aspen can be regenerated using the shelterwood system. The development of such systems again requires greater understanding of the response of aspen regeneration to the extent or intensity of canopy removal.

A final uncertainty is whether the age structures of aspen forests conform exclusively to an even-aged pattern. At the landscape scale, natural aspen and mixed aspen-conifer forests are generally believed to comprise even-aged stands (Peterson and Peterson 1992, Kabzems and Garcia 2004), with the distribution of stand ages shaped by fire-dominated natural disturbance regimes (Cumming et al. 2000). The role of gap dynamics in shaping boreal forest structure may be greater than previously appreciated, however (McCarthy 2001). Cumming et al. (2000) concluded that gap dynamics were functioning in boreal aspen stands, since substantial recruitment of aspen was observed in small natural gaps (mean size $\sim 50 \mathrm{~m}^{2}$ ). The possibility that natural aspen stands are not exclusively even-aged has important implications for natural disturbance-based forest management regimes, including the need to shift to longer rotations and greater use of alternatives to the clearcutting silvicultural system. The incidence of gap dynamics in aspen stands is highly dependent on the ability of aspen suckers to establish and thrive in small openings or under partial canopies.

Long-term observations of aspen regeneration following partial harvesting or the creation of small openings in aspen or aspen-mixedwood forests would help to reduce several uncertainties about aspen silviculture and ecology. Recently, observations of aspen regeneration following partial harvesting have been reported (Prévost and Pothier 2003, Haussler et al. 2007, Gradowski et al. 2008, Man et al. 2008a). Observations of aspen regeneration following the creation of small forest openings are limited, however (Groot et al. 1997, Kabzems 2001).

The objectives of this study were to examine how the density and growth of aspen regeneration in small forest openings is influenced by size of the opening, location relative to the opening edge, and time since harvest. This study takes advantage of a medium-term (10 years) series of aspen regeneration measurements from an experiment that created 5 types of opening in a trembling aspen-dominated forest (Groot et al. 1997).

\section{Methods}

\section{Site description and experimental treatments}

The experiment was located at $47^{\circ} 43^{\prime} \mathrm{N}, 83^{\circ} 11^{\prime} \mathrm{W}$, about $25 \mathrm{~km}$ southeast of the town of Chapleau, Ontario. The forest at the experimental location originated after forest harvesting (presumably of a mixedwood stand), and comprised mainly trembling aspen ( $84 \%$ of the basal area) with minor components of balsam fir (Abies balsamea [L.] - 7\%), white birch (Betula papyrifera Marsh. - 7\%) and white spruce (Picea glauca (Moench) Voss - 1\%). The age of the forest in 1993, when the experiment was established, was about 40 years old. Dominant tree height was $19 \mathrm{~m}$ and stand basal area was 36 $\mathrm{m}^{2} \cdot \mathrm{ha}^{-1}$. The soil is deep, fresh, well-drained silt, with local concentrations of cobbles and boulders in the top $50 \mathrm{~cm}$.

Five types of forest opening were created by forest harvesting in February-March 1993: a 1.5-ha clearcut measuring $100 \mathrm{~m} \times 150 \mathrm{~m}$; three 18 -m-wide east-west strips of $150 \mathrm{~m}$ length; three 9-m-wide east-west strips of $150 \mathrm{~m}$ length; six 18-m-diameter circles and six 9-m-diameter circles (see Groot et al. 1997 for further information on the layout of the experimental treatments). All tree stems were harvested in each treatment; there were no residual stems left within the openings. Deep snow cover at the time of harvest precluded disturbance of the soil surface.

\section{Aspen regeneration measurements}

Permanent circular plots (5- $\mathrm{m}^{2}$ area), marked by an aluminum stake at the plot centre, were established in autumn 1993. Three north-south lines of plots were established to transect the clearcut and each strip, and 1 north-south line of plots was established to transect each circle through its centre. For the 9-m strips and circles, plots were located at the following positions: inside the opening at $2 \mathrm{~m}$ from the north and south stand edges; and outside the opening (within the forest) at $2 \mathrm{~m}, 7 \mathrm{~m}$, and $17 \mathrm{~m}$ from the north and south stand edges. The same plot positions were used for the 18-m strips and circles, but an additional plot was established at the centre of the opening (9 $\mathrm{m}$ from the stand edge). For the clearcut, plots were located at the following positions: within the clearcut at 
$2 \mathrm{~m}, 5 \mathrm{~m}, 15 \mathrm{~m}$, and $30 \mathrm{~m}$ from the north and south stand edges; and outside the clearcut (within the forest) at $2 \mathrm{~m}, 7 \mathrm{~m}$, and $17 \mathrm{~m}$ from the north and south stand edges. For the circular openings, east-west lines of plots were also established, with plot locations at the same distances from the stand edges as in the north-south lines.

Measurements of trembling aspen root suckers and stump sprouts were taken at the end of the $1^{\text {st }}, 2^{\text {nd }}, 4^{\text {th }}, 6^{\text {th }}, 8^{\text {th }}$ and $10^{\text {th }}$ growing season after harvest. Density and height were measured on each occasion and diameter at breast height $(\mathrm{DBH})$ was measured beginning with the $6^{\text {th }}$ growing season after harvest. Although six 9-m-diameter circular openings were created by harvesting, measurements were omitted in 1 circle after the occurrence of seasonal standing water within the opening was noted. For the clearcut, the plots $7 \mathrm{~m}$ and 17 $\mathrm{m}$ from the edge outside the opening (in the forest) were not measured after the $2^{\text {nd }}$ growing season, and the plots $5 \mathrm{~m}$ from the edge inside the opening were not measured for the $4^{\text {th }}$ growing season after harvest. Plots in the east-west lines of 9-m- and 18-m-diameter circles were measured only during the first 2 growing seasons.

A small proportion $(<5 \%)$ of the regeneration stems were Populus balsamifera L. Stems of this species were included with the trembling aspen stems in the analysis and results.

\section{Experimental design and data analysis}

Although the survey lines within individual strips and the clearcut were not independent replicates, they were separated by a substantial distance (mean of $36 \mathrm{~m}$ ). Because it was not feasible to replicate the clearcut treatment, each of the survey lines was considered as a replication, allowing the clearcut to be included in the statistical analysis. The resulting total replication was 9 for $9-\mathrm{m}$ and 18-m strips, 6 for 18-m circles, 5 for 9-m circles, and 3 for the clearcut. This design increases the risk that the effects of opening type are confounded with location (Hurlbert 1984), but this risk is mitigated by the spatial separation between replicates. The effects of opening type and location on aspen density, total height, and DBH were evaluated through analysis of variance with Proc Mixed available in SAS 9.1. The overall experiment was a complete randomized design with repeated measurements over time after harvesting. Fixed factors included 5 opening types (18-m circle, 18-m strip, 9-m circle, 9-m strip, and 100-m clearcut) and 2 locations (inside and outside opening). Planned orthogonal contrasts were performed when fixed factors or their interactions were significant $(\mathrm{P}<0.05)$. The density, height, and $\mathrm{DBH}$ of aspen regeneration were averaged across regeneration plots (weighted means for height and DBH by density) by opening type, location, and year before analysis of variance.

The effects of position (north vs. south side of openings) over time after harvesting were examined through analysis of variance for each of the 5 openings and the differences between the north and south sides inside the opening and between the north and south sides outside the opening were obtained using Estimate option available in the Proc Mixed procedure in SAS 9.1. Aspen sucker height and density were averaged by 4 positions, north and south sides inside and outside opening, and 6 times of measurements after harvesting. Measurements from plots at the centers of all openings and from east-west transects were not included in the analysis of position.

Analysis of variance was also conducted to examine the effect of standing trees on regeneration density and height using plots within $2 \mathrm{~m}$ from uncut edges inside openings. The differences among opening types were obtained with Estimate option available in Proc Mixed procedure.

\section{Results}

\section{Aspen regeneration density}

Aspen regeneration density was significantly influenced by opening type, location inside or outside the opening, and time since harvest (Tables 1 and 2). Overall, the clearcut had the highest regeneration density, followed by 18-m strips, 9-m strips, 18-m circles, and 9-m circles (Fig. 1 and Fig. 2).

Table 1. Summary of P-values from ANOVA for density, total height, and diameter of aspen regeneration

\begin{tabular}{|c|c|c|c|c|c|c|}
\hline \multirow[b]{2}{*}{ Sources of variation } & \multicolumn{2}{|c|}{ Density } & \multicolumn{2}{|c|}{ Height } & \multicolumn{2}{|c|}{ Diameter } \\
\hline & DF & $\mathbf{P}$ & DF & $\mathbf{P}$ & DF & $\mathbf{P}$ \\
\hline Opening type $(\mathrm{O})$ & 4 & $<.0001$ & 4 & 0.0006 & 4 & 0.0346 \\
\hline Clearcut vs. strips & 1 & 0.0017 & 1 & 0.7710 & 1 & 0.7250 \\
\hline Clearcut vs. circles & 1 & $<.0001$ & - & - & - & - \\
\hline 9-m vs. $18-m$ circles & 1 & 0.0781 & - & - & - & - \\
\hline 9-m vs. $18-m$ strips & 1 & 0.0586 & 1 & 0.0334 & 1 & 0.0513 \\
\hline 18-m strip vs. $18-\mathrm{m}$ circle & 1 & 0.0302 & 1 & 0.0002 & 1 & 0.0159 \\
\hline 9-m strip vs. 9-m circle & 1 & 0.0190 & - & - & - & - \\
\hline Location (inside or outside opening) (L) & 1 & $<.0001$ & 1 & $<.0001$ & 1 & 0.0009 \\
\hline Time since harvest $(\mathrm{T})$ & 5 & $<.0001$ & 5 & $<.0001$ & 2 & $<.0001$ \\
\hline $\mathrm{O} \times \mathrm{L}$ & 4 & 0.0015 & 4 & 0.3235 & 3 & 0.2154 \\
\hline In vs. Out in $18-\mathrm{m}$ circle & 1 & 0.0063 & - & - & - & - \\
\hline In vs. Out in 18-m strip & 1 & $<.0001$ & - & - & - & - \\
\hline In vs. Out in $9-\mathrm{m}$ circle & 1 & 0.7304 & - & - & - & - \\
\hline In vs. Out in 9-m strip & 1 & 0.0001 & - & - & - & - \\
\hline In vs. Out in clearcut & 1 & $<.0001$ & - & - & - & - \\
\hline $\mathrm{O} \times \mathrm{T}$ & 20 & $<.0001$ & 20 & $<.0001$ & 8 & 0.2089 \\
\hline $\mathrm{L} \times \mathrm{T}$ & 5 & $<.0001$ & 5 & $<.0001$ & 2 & 0.2266 \\
\hline $\mathrm{O} \times \mathrm{L} \times \mathrm{T}$ & 20 & $<.0001$ & 18 & 0.3945 & 6 & 0.7055 \\
\hline
\end{tabular}

Note: - absence of trees precluded the computation of the planned contrasts 
Table 2. Estimated differences in aspen density and height between openings, for all years on all plots located within the openings combined

\begin{tabular}{lcccccc}
\hline & \multicolumn{2}{c}{ Estimated difference } & & \multicolumn{2}{c}{ P $>$ F } \\
\cline { 2 - 3 } \cline { 5 - 6 } Opening comparison & $\begin{array}{c}\text { Density } \\
\text { (stems per ha) }\end{array}$ & $\begin{array}{c}\text { Height } \\
(\mathbf{c m})\end{array}$ & & $\begin{array}{c}\text { Density } \\
(\text { stems per ha) }\end{array}$ & $\begin{array}{c}\text { Height } \\
(\mathbf{c m})\end{array}$ \\
\hline Clearcut minus strips & 31593 & -23 & & 0.0332 & 0.5516 \\
Clearcut minus circles & 65792 & - & & $<.0001$ & - \\
Strips minus circles & 34200 & - & & 0.0003 & - \\
18-m minus 9-m strip & 6593 & 20 & & 0.2329 & 0.1968 \\
18-m minus 9-m circle & 16 & 126 & - & & 0.0257 & - \\
\hline
\end{tabular}

Note: - absence of trees precluded the computation of the planned contrasts

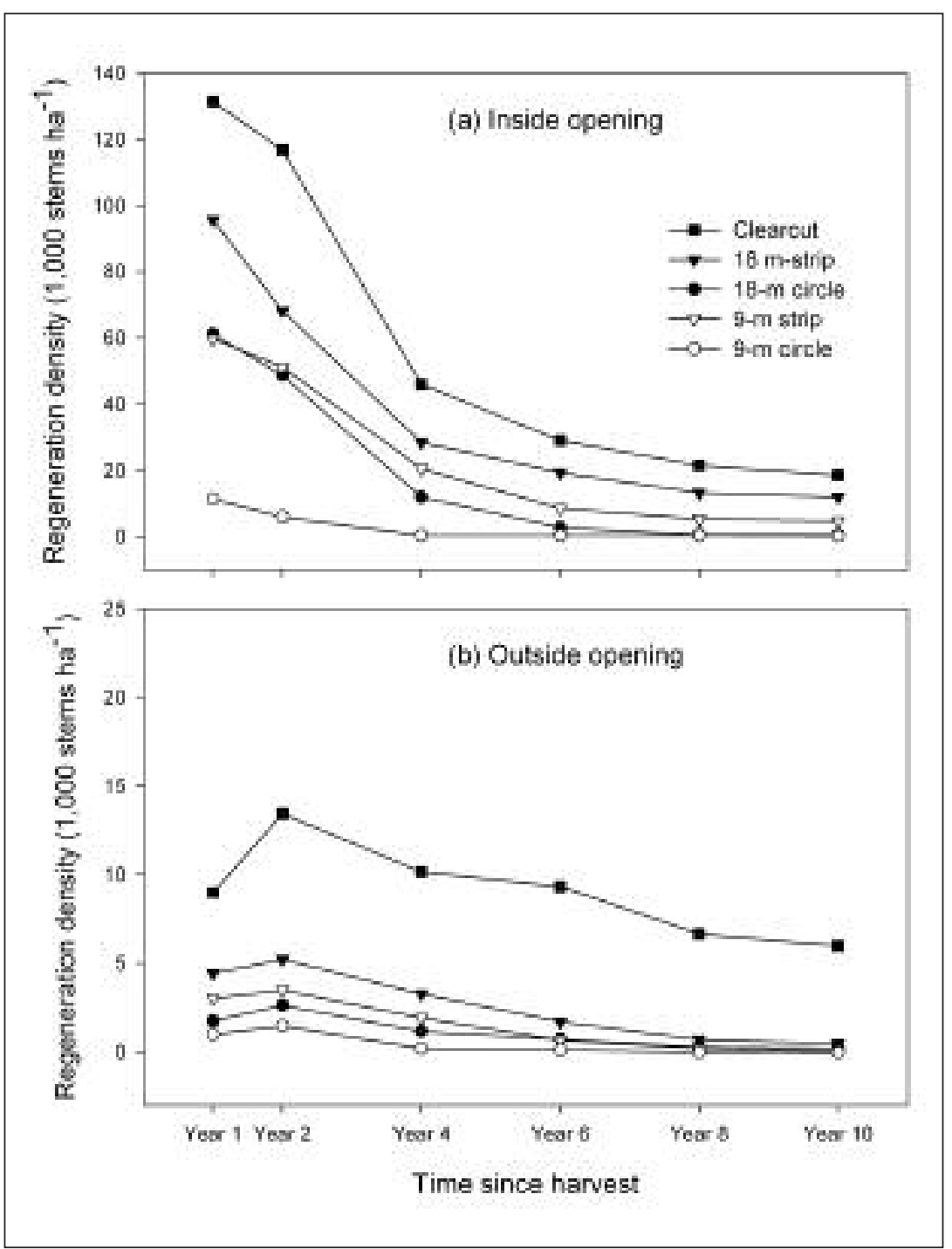

Fig. 1. Temporal trends of regeneration density (least square mean) by opening type and location a) inside or b) outside opening.

Orthogonal contrasts indicated that the differences among opening types existed mainly between clearcut and other openings (circles and strips) and between circles and strips (both 9-m and 18-m sizes), and that these differences generally decreased over time (significant $\mathrm{O} \times \mathrm{T}$ interaction). Over time, aspen density inside the openings peaked in the $1^{\text {st }}$ year following harvesting and then decreased steadily, down to nearly 0 in the $9-\mathrm{m}$ and $18-\mathrm{m}$ circles. Ten growing seasons after harvest, an aspen stem was present inside only 1 of the five $9-\mathrm{m}$ circles, and aspen stems were present inside 3 of the six $18-\mathrm{m}$ circles. Average regeneration density at year 10 was 18600 stems per ha in the clearcut, 11900 stems per ha in the 18 -m strips, 4600 stems per ha in the 9-m strips, 600 stems per ha in the $18-\mathrm{m}$ circles, and 200 stems per ha in the 9-m circles. Outside the openings, maximum densities generally occurred in the $2^{\text {nd }}$ year after harvest and declined to near 0 for all treatments except the clearcut (Table 1; Fig. 1b). Aspen density was significantly greater inside than outside openings, except in the 9-m circles, where no statistical difference was found between inside and outside opening after harvest (significant $\mathrm{O} \times \mathrm{L}$ interaction in Table 1). The differences between clearcut and other openings were relatively smaller inside than outside openings (Fig. 1).

Both inside and outside openings, regeneration density was generally greater on the north side of the opening than on the south side (Fig. 3a and 3b). However, significant differences only occurred inside the openings in the first 4 years since harvest for $18-\mathrm{m}$ strips and in the first 2 years since harvest for 9-m strips and circles and 18-m circles. No statistical difference in regeneration density between the north and south sides of openings was found for the clearcut and between the north and south outside openings for circles and strips.

At a position $2 \mathrm{~m}$ from the forest edge within the opening, aspen regeneration density was much greater $(\mathrm{p}<0.05)$ on the north side than on the south side for the clearcut, 18-m strip and circle, and 9-m strip (Table 3, Fig. 2). Density was also greater on the north side than the south side for the 9-m circle, but this difference was not statistically significant. In the clearcut, the impact of standing trees on regeneration density generally did not extend beyond $5 \mathrm{~m}$ from the forest edges (Fig. 2a).

The development of other species was not assessed in this study, but the growth of dense layers of shrubs (mainly Corylus cornuta Marsh. and Acer spicatum Lam.) was observed within openings at locations where trembling aspen regeneration was sparse or absent.

\section{Aspen regeneration height and diameter}

The height and diameter of aspen regeneration also differed significantly among opening types, locations, and time since harvest, and the height differences among opening types and 


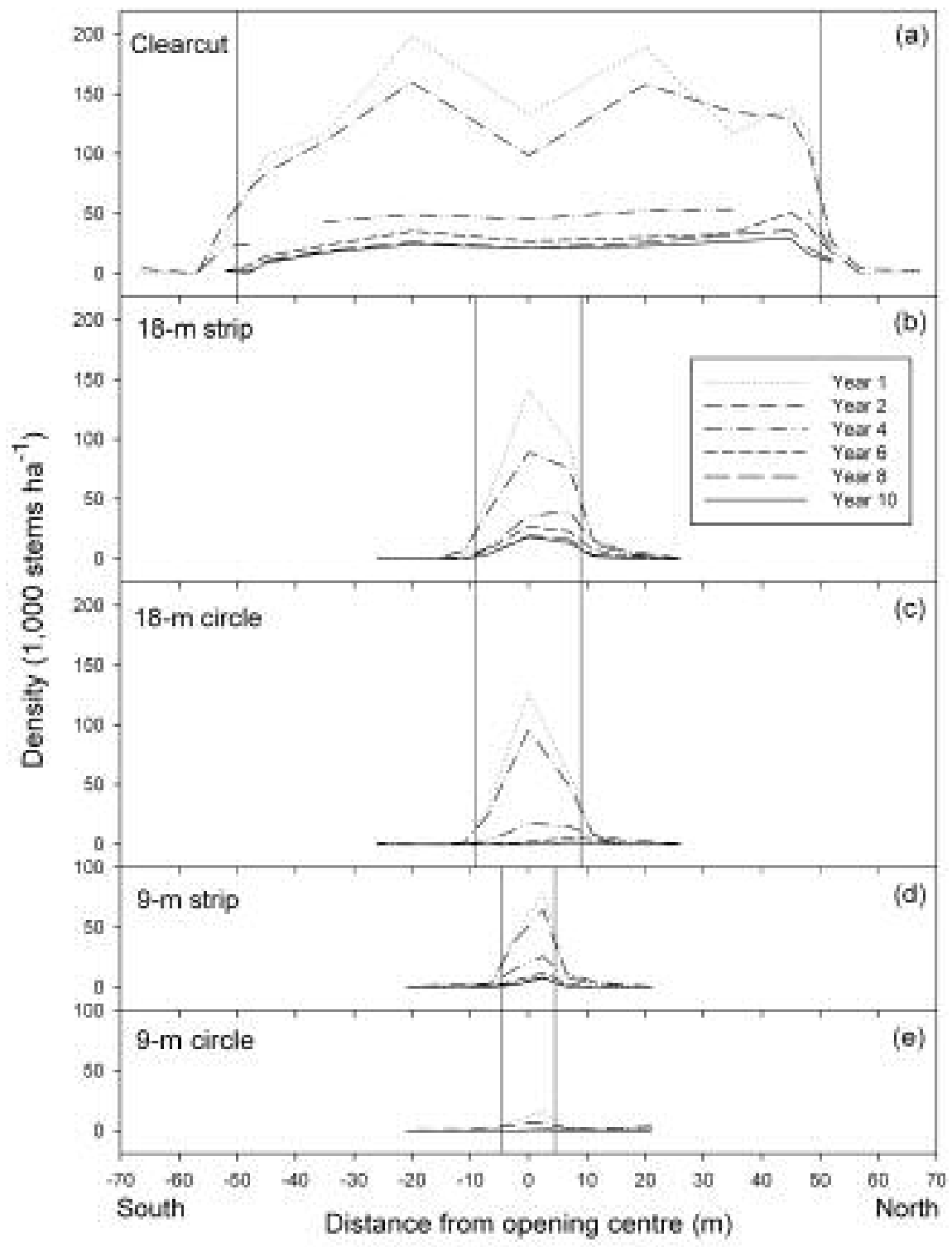

Fig. 2. Trembling aspen regeneration density in north-south transects across 5 opening types. Solid vertical lines indicate the edge of the opening.

locations increased over time (Tables 1 and 2; Fig. 3 to Fig. 6). The aspen regeneration stems in strips were taller and larger in diameter than those in circles, but were not statistically different in size from those in the clearcut. Over time, aspen regeneration stems became taller and larger, except outside the 9-m circle where all stems died out following the $6^{\text {th }}$ growing season after harvest. The average height of aspen regeneration inside the openings by year 10 was $4.2 \mathrm{~m}$ and $3.5 \mathrm{~m}$ in the $18-\mathrm{m}$ and $9-\mathrm{m}$ strips, compared to $3.9 \mathrm{~m}$ in the clearcut and $1.9 \mathrm{~m}$ in the $18-\mathrm{m}$ and $9-\mathrm{m}$ circles. Inside the clearcut, regeneration height increased from the intact forest into the opening and reached near maximum values $5 \mathrm{~m}$ away the forest edge (Fig. 6a). Inside the clearcut, the height of the tallest aspen stems per plot averaged $5.59 \mathrm{~m}$ at year 10 .

Within openings, differences in average height between the south and north sides were not significant, except in the 9-m circles at year 2 where stems in the north half of the opening were $40 \mathrm{~cm}$ taller than those in the south half (Fig. 3c). Outside the openings, however, the differences between the north and south halves varied inconsistently from positive 
Table 3. Estimated differences in aspen density and height between the north and south sides of openings, for plots located $2 \mathrm{~m}$ from the stand edge inside the opening

\begin{tabular}{lccccc}
\hline & \multicolumn{2}{c}{$\begin{array}{c}\text { Estimated difference } \\
\text { (north minus south) }\end{array}$} & & \multicolumn{2}{c}{$\mathbf{P}>\mathbf{F}$} \\
\cline { 2 - 3 } \cline { 5 - 6 } Opening comparison & $\begin{array}{c}\text { Density } \\
\text { (stems per ha) }\end{array}$ & $\begin{array}{c}\text { Height } \\
\text { (cm) }\end{array}$ & & $\begin{array}{c}\text { Density } \\
\text { (stems per ha) }\end{array}$ & $\begin{array}{c}\text { Height } \\
\text { (cm) }\end{array}$ \\
\hline Clearcut & 30000 & -0.4 & & 0.0291 & 0.9840 \\
18-m strip & 25148 & -8.8 & & 0.0020 & 0.4677 \\
18-m circle & 23222 & - & & 0.0174 & - \\
9-m strip & 15889 & 21.7 & & 0.0446 & 0.0788 \\
9-m circle & 3696 & - & 0.7236 & - \\
\hline
\end{tabular}

Note: - absence of trees precluded the computation of the planned contrasts.

and negative directions and significance did occasionally occur including 9-m circle at year 2, 18-m circle at year 4, 9$\mathrm{m}$ strip at year 8, and clearcut at year 6 (Fig. 3d). Similarly, aspen regeneration height at a distance $2 \mathrm{~m}$ from the forest edge inside the openings did not differ significantly between the north and south sides in all opening types (Table 3 ).

\section{Discussion}

Density of aspen regeneration

A comparison of aspen density in the clearcut with values in the literature does not indicate any unusual factor inhibiting sucker initiation and development in this experiment. The $1^{\text {st }}$-year clearcut aspen density of 131400 stems per ha and the $10^{\text {th }}$-year density of 18600 stems per ha were both within the high end of the range of values for aspen regeneration on clearcuts at corresponding ages reported by Doucet (1989) and by Petersen and Petersen (1992), and close to the observations by Man et al. (2008b) in the same area of northeastern Ontario.

The strong increase in aspen regeneration density with size of opening is consistent with greater soil temperature and light levels (Carlson and Groot 1997, Groot et al 1997) and reduced hormonal suppression of sucker development by canopy crowns (Frey et al. 2003) in larger openings. The experimental configuration makes it possible to draw some

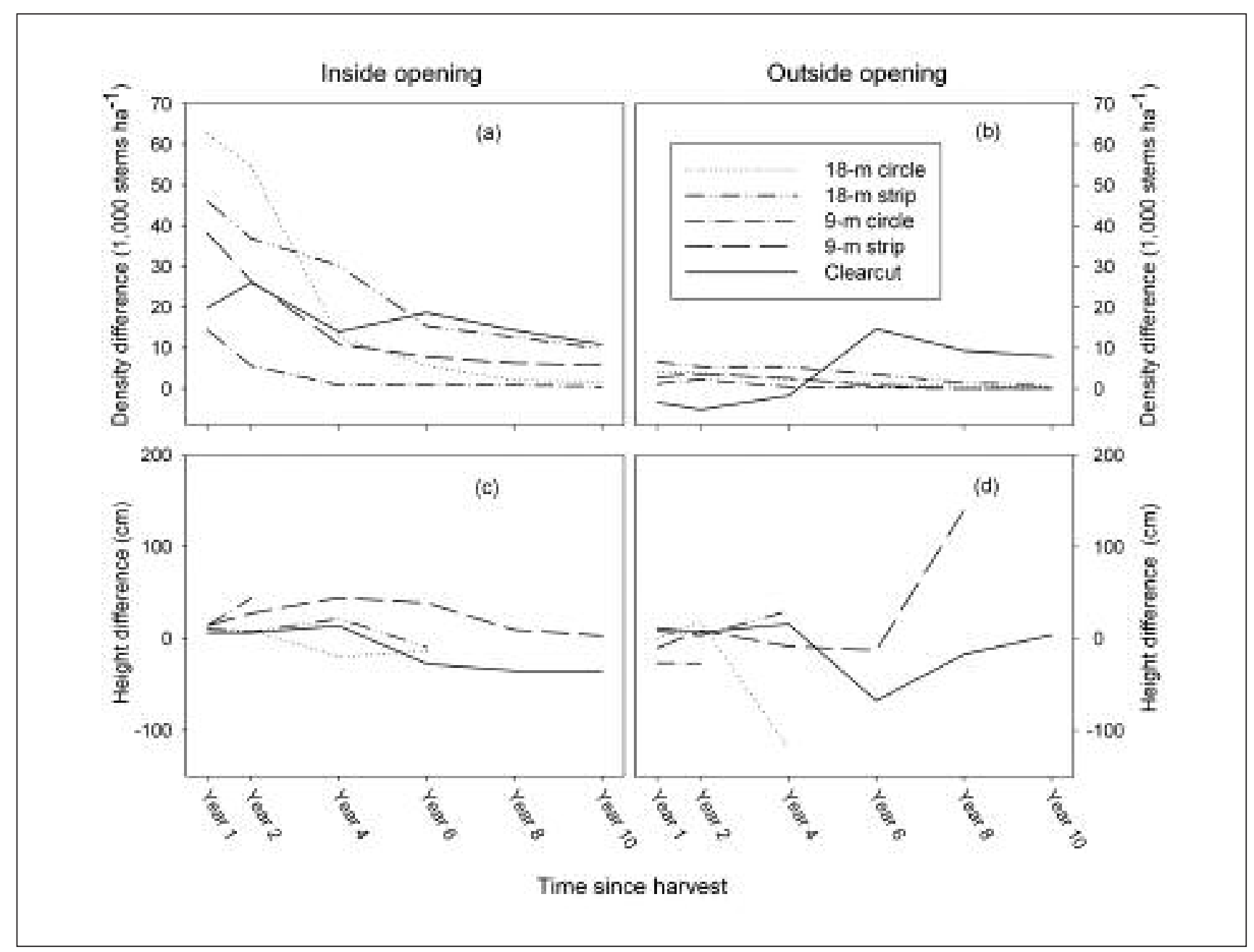

Fig. 3. Aspen regeneration density and height differences between north and south sides of openings, inside and outside openings. Differences are expressed as north value minus south value. 


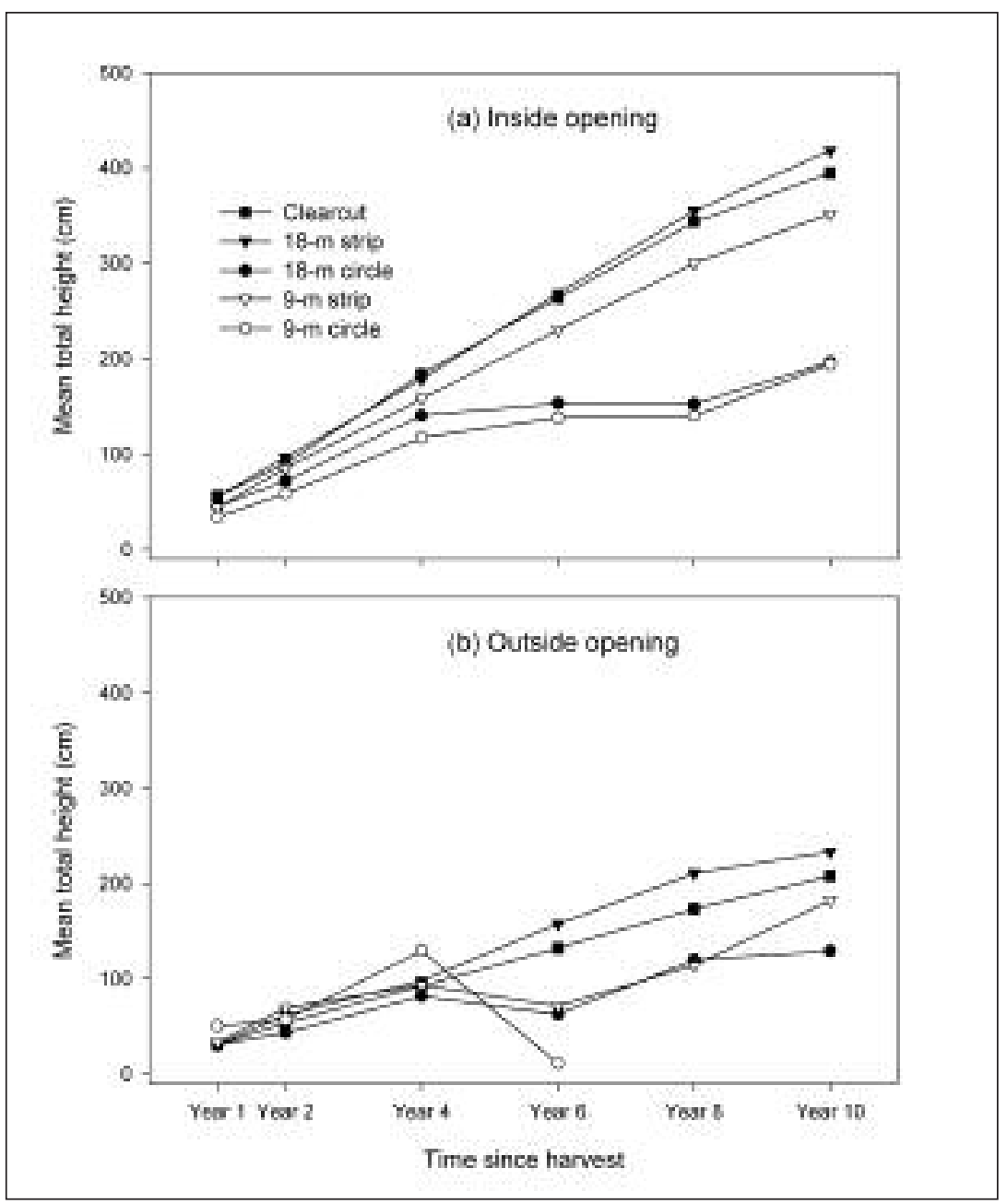

Fig. 4. Temporal trends of regeneration height (least square mean) by opening type and location a) inside or b) outside opening.

inferences about the relative roles of growth regulators and soil temperature in aspen sucker development. First, the reduction of apical dominance by overstory removal was sufficient by itself to initiate significant suckering $\left(1^{\text {st }}\right.$-year regeneration density) in all openings at a position $2 \mathrm{~m}$ north of the southern stand edge, even though soil temperature at this position in the 9-m openings and in the 18-m circle was similar to that under an intact forest (Groot et al. 1997). Second, higher soil temperature further stimulates suckering, based on the fact that first year densities were significantly greater within the openings $2 \mathrm{~m}$ south of the northern stand edge than $2 \mathrm{~m}$ north of the southern stand edge, where distances to decapitated mature trees were the same, but soil temperatures differed by $4^{\circ} \mathrm{C}$ (Groot et al. 1997).

The strong decline in aspen density with time since harvest is consistent with other results from clearcuts and partial cuts (Doucet 1989, Peterson and Peterson 1992, Prévost and Pothier 2003, Man et al. 2008a). The mechanism for this reduction differs with the size of opening. Within the clearcut, competition is among aspen suckers and with woody shrubs, and mortality largely results from a self-thinning process, where smaller stems that fall behind in height growth are eliminated (Doucet 1989, Frey et al. 2003). As the size of the opening becomes smaller, however, the shading from adjacent standing trees exerts a greater competitive effect within the opening on aspen suckers.

The time-dependent density pattern and its interaction with opening type underscore the need to avoid making conclusions based on observations from only the first few years since harvesting. For example, Haeussler et al (2007) conjectured, based on $3^{\text {rd }}$-year results, that 2-storied aspen stands could result from partial cuts that removed between $1 / 3$ and $1 / 2$ of an aspendominated overstory. Given the pattern of strong decline in density to age 10 and the reduced likelihood of aspen regeneration to further survive and reach larger sizes under forest canopies over time (Man et al. 2008a), such a conjecture must be considered as highly speculative.

The effects of opening type on density were more pronounced immediately after harvest than 10 years after harvest (strong opening type $\times$ time since harvest interaction). It is noteworthy, however, that while initial aspen densities within the 9-m and 18 -m circular openings were substantial 1 year after harvest (11 300 and 61200 stems per ha, respectively), densities had declined to near-negligible values (200 and 600 stems per ha, respectively) by 10 years after harvest. Under our experimental conditions, openings must be larger than $254 \mathrm{~m}^{2}$ (18-m circles), or equivalently, larger than 1 tree height in diameter, to sustain significant densities and growth of aspen regeneration.

\section{Height and diameter of aspen regeneration}

The 5.59-m dominant height of aspen in the clearcut at 10 years is consistent with dominant height values reported by Peterson and Peterson (1992) and within the lower part of the range reported by Doucet (1989). The greater average height and diameter of aspen regeneration within the clearcut and the 18-m and 9-m strips are likely due to higher light levels than within the circles. First growing season light levels at the strip centres were about $68 \%$ and $57 \%$ of above-canopy values for the 18-m and 9-m strips, respectively, compared to $100 \%$ in the clearcut, $55 \%$ in the $18-\mathrm{m}$ circle, and $26 \%$ in the $9-\mathrm{m}$ circle (Groot et al. 1997). The mean light levels within the circles were less than those in strips of equal width due to the shade of standing trees in the east-west direction. The direct dependence of aspen height development on light levels in small openings is consistent with results from partial harvests of various intensities that initially provided about $40 \%$ to $50 \%$ of above-canopy light (Prévost and Pothier 2003, Man et al. 2008a). The light levels under these partial canopies are lower than fully open conditions, but possibly sufficient for survival and some reasonable growth (Man et al. 2008a). Other than light transmission from the overstory canopy, comparison of aspen regeneration heights among opening types also needs consideration of density and consequently competition for light among young aspen trees. For instance, aspen regenera- 

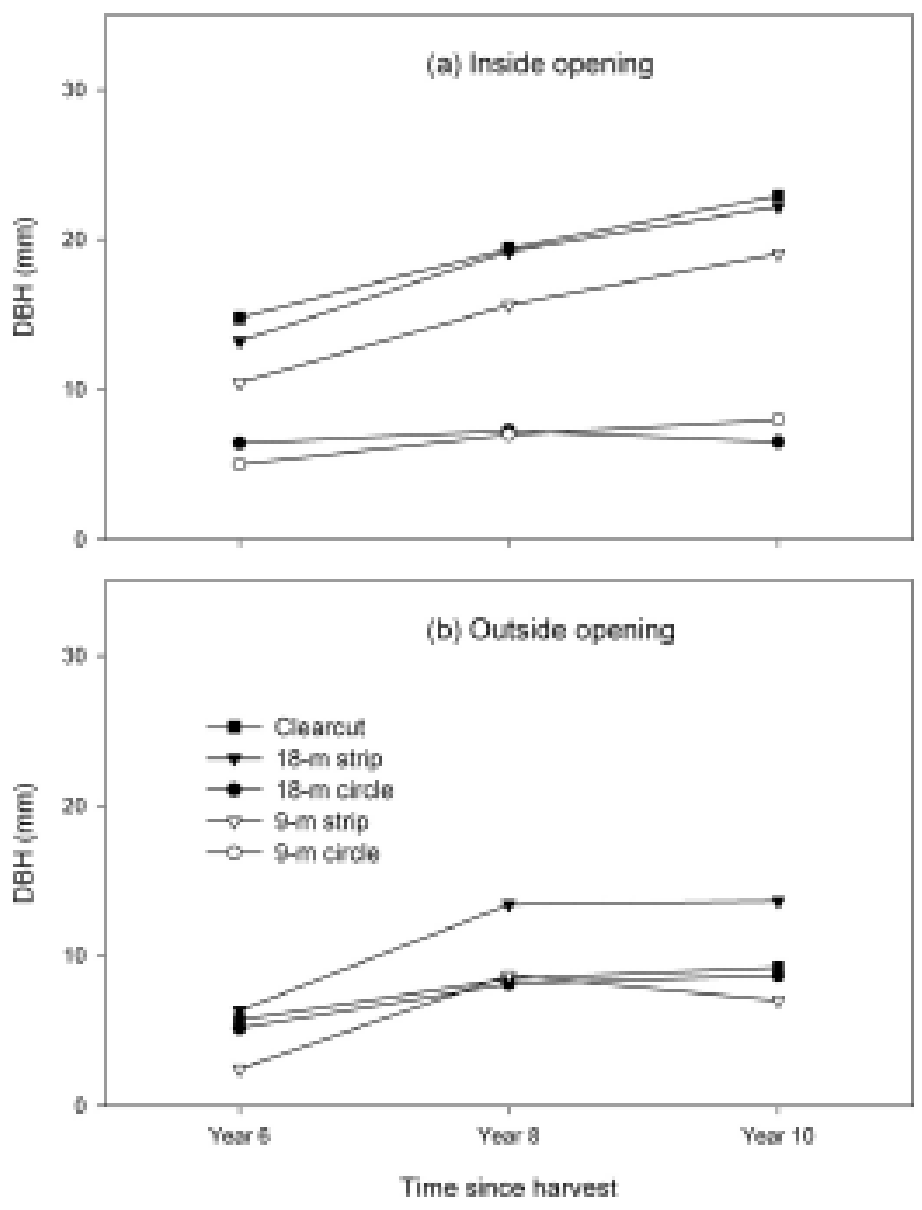

Fig. 5. Temporal trends of regeneration diameter (least square mean) by opening type and location a) inside or b) outside opening.

tion in open strips was significantly lower in density, but capable of maintaining height similar to the clearcut (Table 1), despite reduced light availability (Groot et al. 1997). This may also partially be true for the lack of difference in height of aspen regeneration between $2-\mathrm{m}$ positions within the opening from the north and south edges. For example, only 1 stem was present at the south edge of the clearcut at year 10, compared to 24 stems at the same position relative to the north edge.

Reducing uncertainties about trembling aspen silviculture and ecology

This study indicates that it is feasible to reduce aspen regeneration through the use of small openings, which could contribute to the silvicultural objective of regenerating conifers or creating mixedwood stands in patches, which occur naturally in canopy gaps (Kneeshaw and Bergeron 1998, Hill et al. 2005). Circular openings with a diameter of about 1 tree height or less were more effective in inhibiting the development of aspen regeneration than strips of similar width. Aspen regeneration in the 18-m strip was better than that in the 9-m strip and not much different from that in the clearcut, suggesting that the width of east-west strip openings must be less than $1 / 2$ tree height in order to effectively suppress aspen regeneration. It is clear that openings must be much smaller than a previous recommendation of 0.81 ha (Ohmann et al. 1978) to successfully control aspen regeneration. It should be emphasized that openings small enough to control aspen regeneration may have little impact on more shade-tolerant competitors such as mountain maple that can thrive under partial light levels (Bell 1991, MacDonald and Thompson 2003, Man et al. 2008b), and may simply replace a shade-intolerant competitor with a more shade-tolerant one.

With respect to the converse silvicultural objective, this study reinforces the traditional view that the clearcut silvicultural system is best suited for managing trembling aspen (Doucet 1989). Density and growth are greatest in large openings where suckering is not inhibited by low soil temperatures, or by the apical dominance of canopy crowns, and where growth is not restricted by light levels. However, some aspen regeneration may persist in the understory under $40 \%$ to $50 \%$ of full light (Man et al. 2008a, 2008b), despite reduced growth rates and possible higher mortality. Thus, partial harvesting that removes $40 \%$ to $60 \%$ of the overstory canopy could effectively reduce, not eliminate, sucker density and growth, and at the same time allow reasonable growth of shade-tolerant conifers, reducing the need of stand tending to grow conifers or mixedwoods (MacDonald et al. 2004). Compared to the circular openings, the 9-m strip is less effective in suppressing aspen regeneration, but has greater operational feasibility in creation of mixedwood stands with alternating conifers and hardwood patches (MacDonald and Thompson 2003). For example, alternating corridors of spruce and aspen could reduce the gradual dominance of fast-growing aspen over slow-growing spruce and support application of a dual rotation system in which aspen is harvested every entry (e.g., 50-year intervals) and spruce is harvested every $2^{\text {nd }}$ entry (MacDonald and Thompson 2003). The removal of aspen corridors could be delayed until establishment of regeneration in conifer corridors, potentially reducing the need and cost for stand tending (MacDonald et al. 2004).

The results of this study suggest that gaps of 1 tree height or greater in diameter are probably required in boreal Ontario to sustain aspen regeneration and produce multi-aged aspen stands through gap dynamics. The creation of a gap with this dimension requires the death of 25 to 40 trees in fully stocked aspen stands (Plonski 1974). Mortality of individual aspen overstory trees in fully stocked stands would create gaps that are far too small to initiate gap dynamics. Disturbances such as wind, insect or disease, however, could result in the mortality of larger patches (Kneeshaw and Bergeron 1998). The number of trees required to create an opening conducive to the regeneration of aspen may be considerably lower in old 


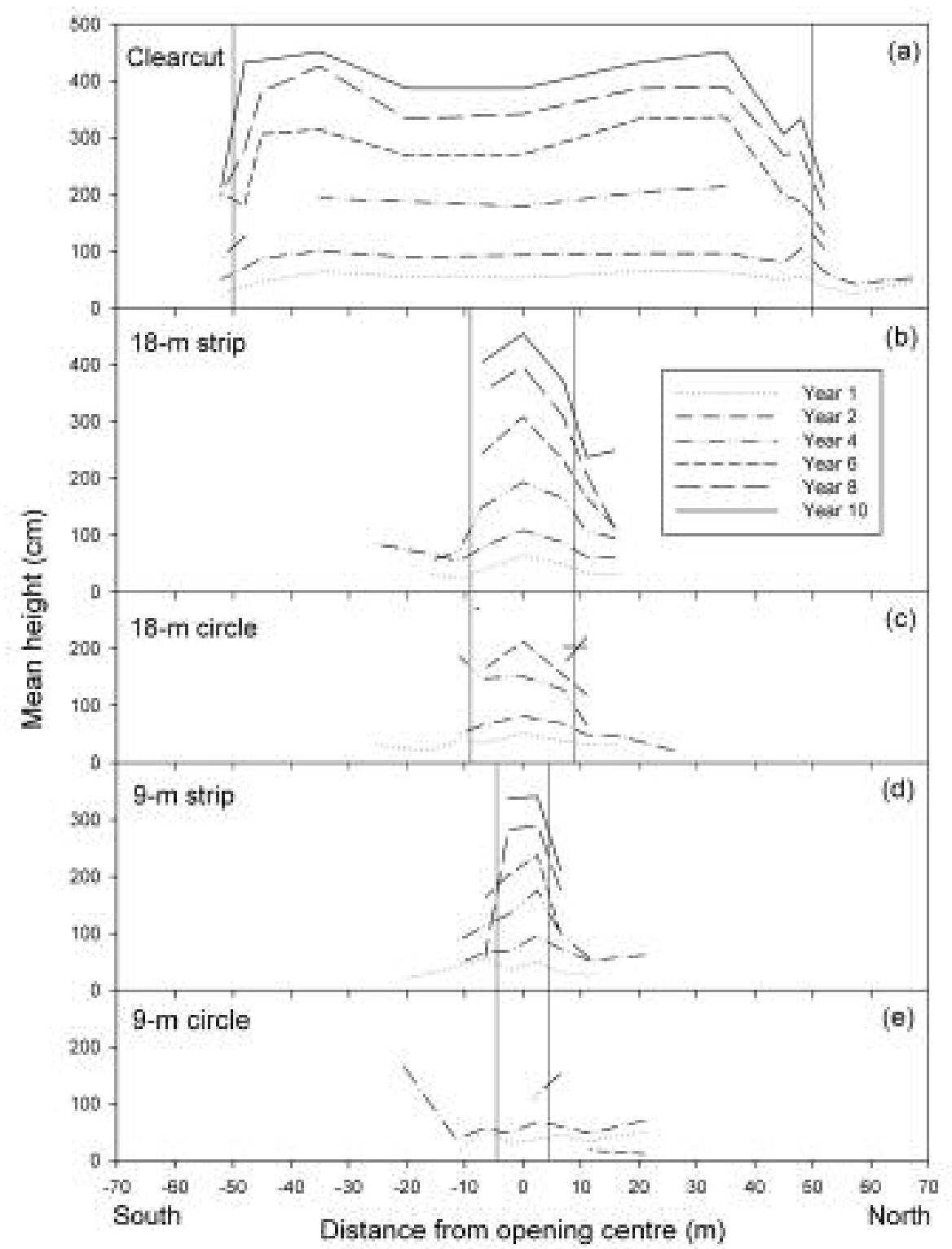

Fig. 6. Trembling aspen regeneration height in north-south transects across 5 opening types. Solid vertical lines indicate the edge of the opening.

aspen stands because of lower site occupancy and because of the greater area occupied by individual trees, consistent with the observation that frequency and size of natural gaps increases with stand age (Kneeshaw and Bergeron 1998, Hill et al. 2005).

\section{Acknowledgements}

This study was funded by Northern Ontario Development Agreement, Northern Forest Program. Garth Mitchell and Mike Adams provided skilled technical assistance in carrying out the field, data compilation, and report production aspects of this work.

\section{References}

Bell, F.W. 1991. Critical silvics of conifer crop species and selected competitive vegetation in northwestern Ontario. For. Can., Great Lakes For. Cent., Ont. Min. Nat. Resour., Sault Ste Marie, ON.

Carlson, D.W. and A. Groot. 1997. Microclimate of clear-cut, forest interior, and small openings in trembling aspen forest. Agric. For. Meteorol. 87: 313-329.

Cumming, S.G., F.K.A. Schmiegelow and P.J. Burton. 2000. Gap dynamics in boreal aspen stands: is the forest older than we think? Ecol. Appl. 10: 744-759.

Doucet, R. 1989. Regeneration silviculture of trembling aspen. For. Chron. 65: 23-27. 
Frey, B.R., V.J. Lieffers, S.M. Landhäusser, P.G. Comeau and K.J. Greenway. 2003. An analysis of sucker regeneration of trembling aspen. Can. J. For. Res. 33: 1169-1179.

Gradowski, T., D. Sidders, T. Keddy, V.J. Lieffers and S.M. Landhäusser. 2008. Effects of overstory retention and site preparation on growth of planted white spruce seedlings in deciduous and coniferous dominated boreal plains mixedwoods. For. Ecol. Manage. 255: 3744-3749.

Groot, A., D.W. Carlson, R.L. Fleming and J.E. Wood. 1997. Small openings in trembling aspen forest: microclimate and regeneration of white spruce and trembling aspen. Natural Resources Canada, Canadian Forest Service, Great Lakes Forestry Centre, Sault Ste. Marie, ON. NODA/NFP Tech. Rep. TR-47. 25 p.

Haeussler, S., Y. Bergeron, S. Brais and B.D. Harvey. 2007. Natural dynamics-based silviculture for maintaining plant biodiversity in Populus tremuloides-dominated boreal forests of eastern Canada. Can. J. Bot. 85: 1158-1170.

Hill, S.B., A.U. Mallik and H.Y.H. Chen. 2005. Canopy gap disturbance and succession in trembling aspen dominated boreal forests in northeastern Ontario. Can. J. For. Res. 35: 1942-1951.

Hurlbert, S.H. 1984. Pseudoreplication and the design of ecological field experiments. Ecol. Monogr. 54: 187-211.

Kabzems, R. 2001. Regenerating boreal mixedwoods: three-year results of a group shelterwood silviculture system in trembling aspen - white spruce stands. British Columbia Forest Service Forest Research Note \#PG-24.

Kabzems, R. and O. Garcia. 2004. Structure and dynamics of trembling aspen - white spruce mixed stands near Fort Nelson, B.C. Can. J. For. Res. 34: 384-395.

Kneeshaw, D.D. and Y. Bergeron. 1998. Canopy gap characteristics and tree replacement in the southeastern boreal forest. Ecology 79: 783-794.

MacDonald, G.B., M.L. Cherry and D.J. Thompson. 2004. Effect of harvest intensity on development of natural regeneration and shrubs in an Ontario boreal mixedwood stand. For. Ecol. Manage. 189: 207-222.
MacDonald, G.B. and D.J. Thompson. 2003. Responses of planted conifers and natural hardwood regeneration to harvesting, scalping, and weeding on a boreal mixedwood site. For. Ecol. Manage. 182: 213-230.

Man, R., G.J. Kayahara, J.A. Rice and G.B. MacDonald. 2008a. Eleven-year response of a boreal mixedwood stand to partial harvesting: light, vegetation and regeneration dynamics. For. Ecol. Manage. 255: 697-706.

Man, R., J.A. Rice and G.B. MacDonald. 2008b. Long-term responses of planted conifers, natural regeneration, and vegetation to harvesting, scalping, and weeding on a boreal mixedwood site. In preparation.

McCarthy, J. 2001. Gap dynamics of forest trees; a review with particular attention to boreal forests. Environ. Rev. 9: 1-59.

Ohmann, L.F., H.O. Batzer, R.R. Buech, D.C. Lothner, D.A. Perala, A.L. Schipper Jr. and E.S. Verry. 1978. Some harvest options and their consequences for the aspen, birch, and associated conifer forest types of the Lake States. USDA Forest Service General Technical Report NC-48, North Central Forest Experiment Station. 34 p.

Peterson, E.B. and N.M. Peterson. 1992. Ecology, management, and use of aspen and balsam poplar in the prairie provinces. Forestry Canada, Northwest Region, Northern Forestry Centre, Edmonton, AB. Special Report 1.

Plonski, W.L. 1974. Normal yield tables (metric) for major forest species of Ontario. Ontario Ministry of Natural Resources. 40 p.

Prévost, M. and D. Pothier. 2003. Partial cuts in a trembling aspen -conifer stand: effects on microenvironmental conditions and regeneration dynamics. Can. J. For. Res. 33: 1-15.

Quinn, R.D. and L. Wu. 2001. Quaking aspen reproduce from seed after wildfire in the mountains of southeastern Arizona. In W.D. Shepperd, D. Binkley, D.L. Bartos, T.J. Stohlgren and L.G. Eskew (compilers). Sustaining aspen in western landscapes: symposium proceedings. pp. 369-376. USDA Forest Service Proceedings RMRSP-18, Rocky Mountain Research Station. 460 p.

Ruark, G.A. 1990. Evidence for the reserve shelterwood system for managing quaking aspen. North. J. Appl. For. 7: 58-62. 